\title{
論文特集「生物活性物質」
}

（日本化学会誌，1981，（5), p. 629 634)

(C) 1981 The Chemical Society of Japan

\section{ワモンゴキブリの性フェロモンミミクスと その光学異性体の活性}

\author{
（1980 年 10 月 14 日受理）
}

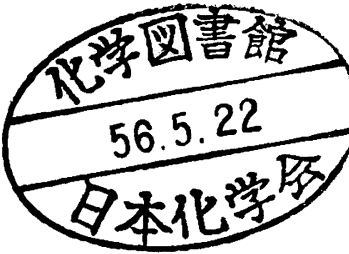

高 柳 久男・西 野 親 生*

\begin{abstract}
著者らにより，ワモンゴキブリの性フェロモンミミクスとしてすでに報告されている（十)-trans-ベ

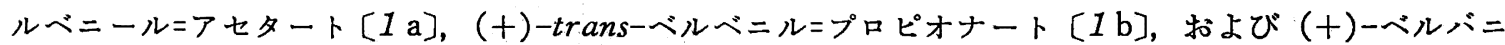
ルニアセタート [2a]の光学巽性体を調製し、ワモンゴキブリの雄を用いて性フェロモン活性を試験し た。今回，(+)ーベルバニルニプロピオナート [2b]とその光学異性体もつくり，同様の活性を試験し た。その結果，[2 b]には活性があり，ミミnスの中でもっとも強いものであった。一方，ミミクスの 光学異性体 $[(-)$-体 $]$ にはすべて活性が見られなかった。このことにより，ワモンゴキブリの性フェ ロモンに関係した受容器はキラルな性質をもつことが明らかとなった。
\end{abstract}

\section{1 緒言}

ワモンゴギブリ(Periplaneta americana L.) の雌成虫が放出

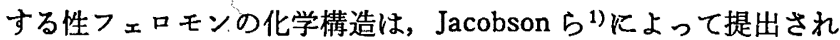
たが，この構造は誤りであった。近年，Persoonsらゔたりふた たびこのフェロモンの平面構造が出され，1979 年に合成法 ${ }^{8)}$ と 線解析など)により，性フェロモンの成分の一つ；ペリプラノンー Bに立体構造および絶対構造が与えられた。

性フェロモンにかぎらずフェロモンは，化学者にとって構造研 究するための興味ある材料であるが, 行動学者や生理学者にとっ ても重要な研究材料である。しかし，フェロモンはごく微量にし か細離し得ないことが普通で, フェロモンを研究材料にしている すべての研究者の手に渡ることは，きわめて困難である。この 点, フェロモンを合成することは, 化学構造を確かめる上でも， また合成したものが多くの研究者に補給されるという意味でも， 意義深いことである。

他方，著者らは，フェロモン作用をもつ物質(フェロモンミミ クといら）が昆虫以外の源から大量に得られるなら，フェロモン に関する総合的研究に大きく寄与できるむのと考え，ここ数年来 フェロモンミミクの研究を行なってきた。この目的で著者らは最 初に，植物からワモンゴキブリの雄と雌の成虫を興奮させる物質 であるTーカジノールを単離した5)。これよりさきに, Bowersらの)

三菱化成生命科学研究所, 194 町田市南大谷

1) M. Jacobson, M. Beroza, R.T. Yamamoto, Science, 139, 48(1963).

2) C. J. Persoons, P.E. J. Verwiel, E. Talman, F. J. Ritter, J. Chem. Ecol., 5, 221(1979).

3) W.C. Still, J.Am. Chem.Soc., 101, 2493(1979).

4) M. A. Adams, K. Nakanishi, W.C.Still, E. V. Arnold, J. Clardy, C. J. Persoons, ibid., 101, 2495(1979).

5) C. Nishino, K. Tsuzuki, Botyu-Kagaku, 40, 62(1975).

6) W.S. Bowers, W. G. Bodenstein, Nature, 232, 259 (1971).
はやはり植物から，ワモンゴキブリの雄成虫に性興奮を起こす物 質, $d$-ボルニルニアセタートを発見した。この事実から，著者ら

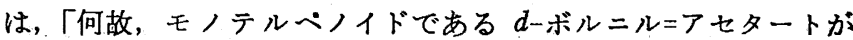
セスキテルペノィドである天然り性フェロモンと同じ作用をるつ のであろらか?」といら疑問を抱いた。そこで $d$-ボルニル=アセ タートと同様に二環性で, gem-ジメチル基をもったモノテルベ ノイド約 20 種類のワモンゴキブリに対する性フェロモン活性を 検索した。その結果，(十)-trans-ベルベニルニアセタート[1 a にd-ボルニルンアセタートよりやや強い活性を見いだしだ)。

[1 a]は分子内に固定されたシクロブタン環を有するが，六員 環内の二重結合が飽和された場合，メチル基およびアセトキシル 基の位置異性体，立体配置異性体，立体配座異性体など多数の異 性体の合成が可能であり，これらの中に活性な物質が発見される ことが予想された。またこれらの類縁体の活性の有無から, 性フ ェロモン作用に必須な因子や，性フェロモン受容器の形状などが わかることも期待される。そこで著者らは，約 70 個の類縁体を 合成して ${ }^{8) \sim 10)}$ 性フェロモン試験をした結果, [1 a $]$ のほかに(十)-

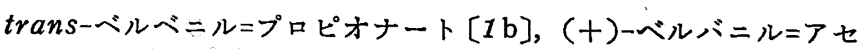
タート[2a]の 2 個に顕著な活性を見いだした ${ }^{10)}$ 。今回は活性の

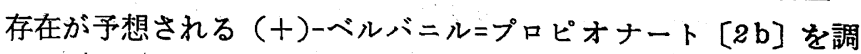
製し，生理活性試験を行なった。

Adams ら4)の研究から, ワモンゴキブリの性フェロモン受容器 はキラルな性質をるつことが示唆されたが，今回活性なミミクス の光学異性体を合成して，これらの異性体の活性試験の結果か

7) C.Nishino, T.R. Tobin, W.S. Bowers, Appl. Ent.Zool. 12, 287(1977).

8) C. Nishino, H. Takayanagi, Agric. Biol. Chem., 43, 1967(1979).

9) C. Nishino, H. Takayanagi, ibid., 43, 2399(1979) ; 44, 1649 (1980) ; H. Takayanagi, C. Nishino, ibid., 44, 2877 (1980).

10） C. Nishino, H. Takayanagi, J. Chem. Ecol., 印刷中. 


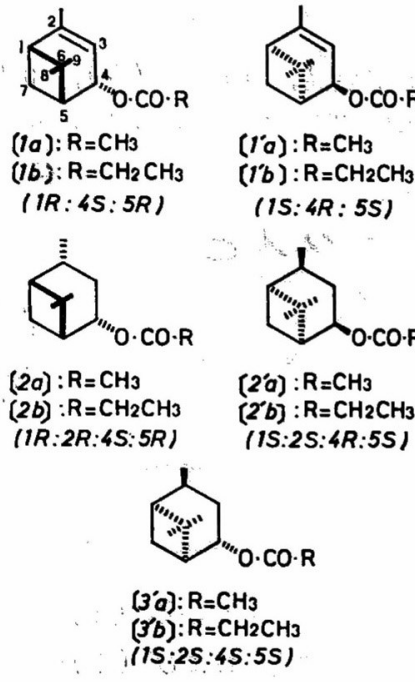

ら, 受容器におけるキラリティーの証明を試みた。

\section{2 結 果}

(十)-ベルバニル=プロピオナート $[2 \mathrm{~b}],[\alpha]_{\mathrm{D}}^{25}=+11.2^{\circ}$ (以後 すべてベンゼン中）は，著者らの合成した（十）-ベルバノール， $[\alpha]_{\mathrm{D}}^{25}=+8.4^{\circ}$ 8) から無水プロピオン酸とピリジンによって調製 した。(ー)-trans-ベルベノールのェステル類である $\left[1^{\prime} \mathrm{a}\right],[\alpha]_{\mathrm{D}}^{25}$ $=-164.5^{\circ}$ と $\left[1^{\prime} \mathrm{b}\right],[\alpha]_{\mathrm{D}}^{25}=-158.2^{\circ}$ は市服の (-)-transベルベノール， $[\alpha]_{\mathrm{D}}^{25}=-122.4^{\circ}$ より常法により調製した。一方, $\left[2^{\prime} \mathrm{a}\right],[\alpha]_{\mathrm{D}}=-12.5^{\circ}$ と $\left[2^{\prime} \mathrm{b}\right],\left[\alpha^{\prime}\right]_{\mathrm{D}}=-11.6^{\circ}$ の母体となる (一)ーベルバノールの合成はうぎのようにして行なった（図式 1 参照)。

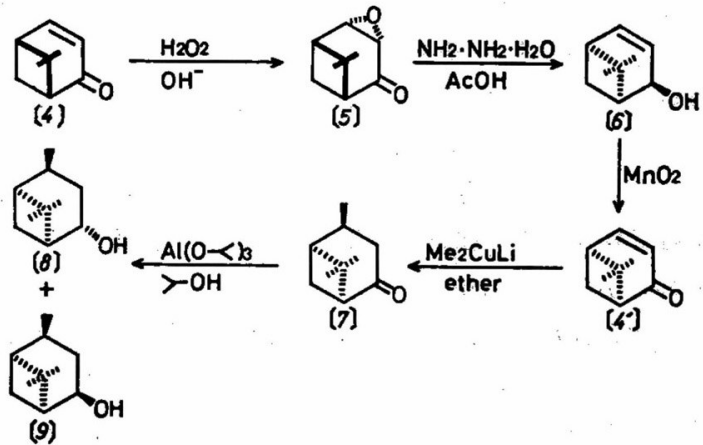

Scheme 1

すでに著者らによってつくられた（十)-アポベルペノン[4]， $\left.[\alpha]_{\mathrm{D}}^{25}=+283.2^{\circ}{ }^{8}\right)$ にアルカリ性条件下, 過酸化水素を作用する ことにより,アポベルベンンエポキシド [5], $\mathrm{mp} 55 \sim 59^{\circ} \mathrm{C}$, $[\alpha]_{\mathrm{D}}^{25}=+156.3^{\circ}$ を $90 \%$ の収率で得た。エポキシケトンをアリ ルアルコールに立体選択的にヒドラジン還元する Wharton 反

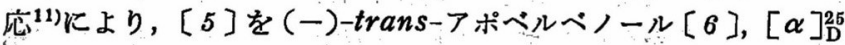
$=-146.2^{\circ}$ に変換した。このさいの収率は $21 \%$ であった。

[6]を酸化マンガン(N)によって酸化し，(一)-アポベルベ， ソ $\left[4^{\prime}\right],[\alpha]_{D}^{25}=-296.3^{\circ}$ とし，これをジメチル銅( I )酸リチ ウムで処理してメチル化すると，(ー)-trans-ベルバノン [7], $[\alpha]_{\mathrm{D}}^{25}=-28.6^{\circ}$ が 81\%の収率で得られた。[7]を Meerwein-

11) P.S. Wharton, D. H. Bohlen, J. Org. Chem., 26, 3615 (1961).
Table 1 Pheromonal activity of sex pheromone mimics and their enantiomers to the American cockroach

\begin{tabular}{|c|c|c|c|}
\hline Compound & $\underset{(\mathrm{mg})}{\text { Amount }}$ & $\begin{array}{l}\text { Number of } \\
\text { repetitions }\end{array}$ & Activity $\left.^{a}\right)$ \\
\hline $\begin{array}{l}(+) \text {-trans-Verbenyl } \\
\text { acetate } \quad[1 \mathrm{a}]\end{array}$ & 0.02 & 20 & $9^{b)}$ \\
\hline $\begin{array}{l}(+) \text {-trans-Verbenyl } \\
\text { propionate } \quad[1 \mathrm{~b}]\end{array}$ & 0.02 & 20 & $15^{b)}$ \\
\hline $\begin{array}{l}(+) \text {-Verbanyl } \\
\text { acetate } \quad[2 \mathrm{a}]\end{array}$ & 0.02 & 20 & $15^{b)}$ \\
\hline $\begin{array}{l}(+) \text {-Verbanyl } \\
\text { propionate }[2 \mathrm{~b}]\end{array}$ & 0.02 & 20 & 18 \\
\hline $\begin{array}{l}(-) \text {-trans-Verbenyl } \\
\text { acetate } \quad\left[1^{\prime} \mathrm{a}\right]\end{array}$ & 0.3 & 5 & $-^{c)}$ \\
\hline $\begin{array}{l}(-) \text {-trans-Verbenyl } \\
\text { propionate } \quad\left[1^{\prime} \mathrm{b}\right]\end{array}$ & 0.3 & 5 & 一 \\
\hline $\begin{array}{l}(-) \text {-Verbany } 1 \\
\text { acetate }\left[2^{\prime} \mathrm{a}\right]\end{array}$ & 0.3 & 5 & 一 \\
\hline $\begin{array}{l}(-) \text {-Verbany } 1 \\
\text { propionate }\left[\mathcal{Z}^{\prime} \mathrm{b}\right]\end{array}$ & 0.3 & 5 & - \\
\hline
\end{tabular}

a) Average number of cockroaches showing typical sexual display within $3 \mathrm{~min}$ in a group containing 25 males.

b) Reported in reference 10).

c) No activity.

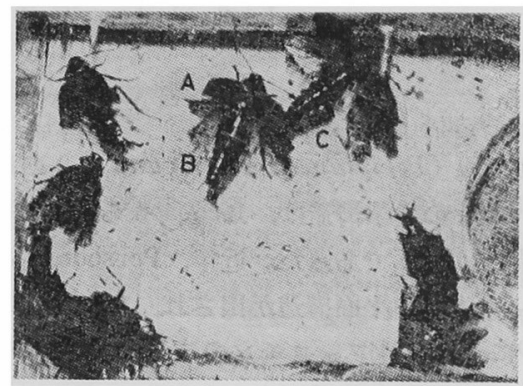

Fig. 1 Typical sexual display of males of the Americăn cockroach induced by $0.02 \mathrm{mg}$ of (+)-verbanyl propionate [2 b]

Vibration of the raised wings (A), extention of the abdomen (B) and attempts to copulate (homosexually in this case) (C) are observed.

Ponndorf 法により還元すると（十)-ネオベルバノール［8]と (一)-ベルバノール[9]の混合物が得られ，この混合物のシリカ ゲルクロマトグラフィーによって純粋な [8], mp 77〜 78 $\mathrm{C}$, $[\alpha]_{\mathrm{D}}^{25}=+15.3^{\circ}$, および $[9], \operatorname{mp} 54 \sim 55^{\circ} \mathrm{C},[\alpha]_{\mathrm{D}}^{25}=-7.8^{\circ}$ を 得た。収率は[8]，[9]それ癷 45，37\%であった。[8]， [9]のいずれ子常法により，アセタートおよびプロピオナート とした。すべての化合物は，ガスクロマトグラフィーによる分析 で，99\% 以上の純度であった。

得られたエステル類は, これらの光学純度を考虑に入れて, $0.3 \mathrm{mg}$ を直接沪紙に浸みこませ，著者らの報告した生理活性試 験法 ${ }^{12)}$ により活性を調べた。 $0.3 \mathrm{mg}$ 供試の試験は, 一つの化合 物につき 5 回くり返された。0.3 mg のレベルで活性を示した化 合物は, ヘキサン溶液とし, 順次希釈して化合物の 0.1, 0.05, $0.02 \mathrm{mg}$ に相当する量を汇紙にとり試験した。各供試量で $5 \sim 10$ 回試験をくり返した。

12) C. Nishino, H. Takayanagi, R. Kimura, Comp. Biochem. Physiol. A, 66, 393(1980). 
生理活性試験の結果は表 1 K示したように，(十)-ベルバニルニ プロピオナート[2 b]が, $0.02 \mathrm{mg}$ で 25 頭の雄成虫の5ち平均 で 18 頭に, 趐を上げてふるわせ, 尾端をのばし, 交尾器をつき 出して交尾しよらとする，性フェロモンによって起こる典型的な 性行動を誘起した (図 1参照)。これは [1 a ] のすべての類縁体の 中でもっとも強いものであった。一方，活性を示したミミミス の，すべての対掌体 [(一)-体] では，0.3 mg といら多量の投与 にもかかわらず，ゴキブリはやや俊敏な行動を示すが，上に述べ た性行動をまったく示さなかった。なお（一)ーネオべルバノール のアセタートとプロピオナートともに活性は認められていない

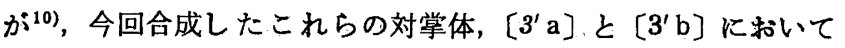
も， $0.3 \mathrm{mg}$ でまったく活性はみられなかった。

\section{3 考察}

(十)-trans-ベルベノールの絶対配置は(1R, 4S, $5 R)$ であり， このものの比旋光度は森 ${ }^{13)} に よ り ク ロ ロ ホ ル ム 中, ~+141^{\circ}$ と報告 されている。著者らの合成したものはクロロホルム中で $[\alpha]_{\mathrm{D}}^{25}=$ $+130^{\circ}$ を示したことから，光学純度は $92 \%$ となる。また（一) trans-ペルペノール [(1S, 4R, 5S)-(一)-2-ピネン-4-オール] については森 ${ }^{13)}$ が $[\alpha]_{\mathrm{D}}^{24}=-135^{\circ}$ (クロロホルム) と報告してお り，著者の用いたものが $[\alpha]_{\mathrm{D}}^{25}=-128.4^{\circ}$ (クロロホルム) であ ったので, 光学純度は $95 \%$ である(十)-ベルバノールi $[(1 R$, $2 R: 4 S, 5 R)-(+)$ ピナン-4-オール] の比旋光度については, はっきり記載したものがない゙)。(ー)-ベルバノール［(1S, 2S， $4 R, 5 S)]$ は新規化合物である。

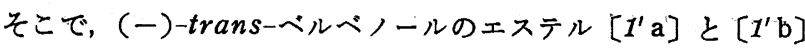
の活性試験のさい, おのおの活性な $[1 \mathrm{a}],[1 \mathrm{~b}]$ か $5 \%$ 含まれ ていることを想定して, $0.3 \mathrm{mg}[0.015 \mathrm{mg}$ の (十)-体の混入 $]$ を最大供試量とした。! 雄のワモンゴキブリにおける性フェロモン によって誘起されるもっとも最初の行動の変化は, “歩行行動など が敏速になることであり，このよらな変化は性フェロモンを闒値 以下で与えたときにもみられる。（一)-体 $0.3 \mathrm{mg}$ を与えた試験 のさい, 雄の行動が俊敏になったのは，あるいは混入していた微 量の (十)-体によるものかも知れない。

昆虫のフェロモンにおいて絶対構造が初めて報告されたのは, キクイムシ (Ips confusus) が出す䔬と木肩の混合物の中から発 見された集合フェロモンのひとう（十)-cis-ベルベノールであ った (1966) ${ }^{15)}$ 。しかし, 単離されるフェロモンが锁量であったこ となどが理由で，その後の絶対構造の決定は，合成的研究に委ね られた。フェロモンの光学異性体の最初の合成は1973 年に森 ${ }^{16)}$ により成され，ヒメカツオブシムシの性ブェロモンの絶対構造が 決定された。その後; おむに森らによる精力的なフェロモンの光 学異性体の合成研究と; それを用いた活性試験により, 不斉原子 をひつフェロモンに拈いては; ほとんど一方の光学異性体のみが 活性をるつことが判明してきた。つまり，昆虫のフェロモン受容 器はキラルな性質をむつことが示されたのである。

ゴキブリの性フェロモンで, 最初に構造が報告された例は，チ

13) K. Mori, Agric. Biol. Chem., 40, . 415(1976).

14) A.F. Regan, Tetrahedron, 25, 3801(1969).

15) R.M. Silverstein, J. O. Rodin, D. L. Wood, Science, 154, 509(1966).

16) K. Mori, Tetrahedron Lett., 1973, 3869.

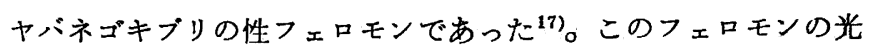
学異性体が合成され ${ }^{18)}$, 活性が調べられたが，異性体間での活性 の差異はみられなかった ${ }^{18)}$ 。一方，ワモンゴキブリの性フェロモ ンに関しては, ラセミ体ではあるが立体異性体が合成されだ) が， この中で唯一つのラセミ体のみが活性を示し ${ }^{8)}$, このラセミ体の 光学分割がなされだ)結果, 一方の光学異性体のみが活性をむち, その対掌体は不活性であることが明らかとなっだ)。のように， ワモンゴキブリにおいても性フェロモン受容器がキラリティーを もつことが示された。

フェロ,モのミミクは従来, 天然のフェロモンと構造が類似し ているものが多い(19)。その点, ここに述べた例のように, 天然の フェロモンとまったく類似していない構造をもったミミクの例は 少ない。この論文にあげたワモンゴキブリの性フェロモンミミク が, 真の性フェロモン受容器に受けとめられているかは不明であ るが, 事実，“雄が性行動を示すことから性フェロモン受容器を刺 激していることは十分考えられる。むしとうならミミクスにおい ても一方の光学異性体に活性があり，対掌体が不活性であること は，珄フェロモン受容器がキラリティーを有することを強く支持 している。

フェロモンにおける不活性な対掌体の役割は大略して，（1） 活性な対掌体に影響を与えない20)。(2) 対掌体の活性を阻害す る21。の二つに分類されるが，このほかに（十）体，(一)-体とむ

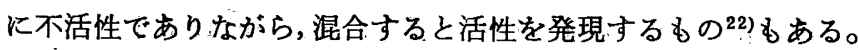

現在, 著者らは,ここに示した不活性な(一)一体の, 活性に対 する影響を調べるとともに, (一)-体が活性をもたないことを， 電気生理学的に証明しょうとしている。

\section{4 実験}

\section{1. 分 析}

比旋光度の測定は二ニオン技研製 PM-201 ポラリメーターを使 用し， $25^{\circ} \mathrm{C}$ でベンゼン溶液で測定した。赤外吸収 (IR) スペク トルは日本分光 IRA-1 型光度計を使用し, 油状の物質は液膜で, 結晶のものは $\mathrm{KBr}$ ペレットで測定した。 ${ }^{1} \mathrm{H}$-核磁気共鳴 (PMR) スペクトルの測定は日立 R-24 型 (60 MHz) 装置を用い, . 内部標 準として TMS を入れ，ク口ロホルムーd 溶液中で測定した。が スクロマトグラフ (GC) は島津製 GC-4 BMPF 型を使用し，3\% OV-225（担体はセライト 545）を充てんした $2 \mathrm{~m} \times 3 \mathrm{~mm}$ のカラ ムを用いて， $110^{\circ} \mathrm{C}$ (キャリ:ヤナガスは窒素, $40 \mathrm{ml} / \mathrm{min}$ ) で測定 した。保持時間 $\left(t_{\mathrm{R}}\right)$ は分で表わした。質量スペクトル $(\mathrm{MS})$ は 島津製 GCMS-7000 型で測定し，このさいのガスクロマトグラフ

17) R. Nishida, H. Fukami, S. Ishii, Experientia, 30, 978 (1974) ; R. Nishida, T.Sato, Y.Kuwahara, H. Fukami, S. Ishii, J. Chem. Ecol., 2, 449(1976).

18) K. Mori, T. Suguro, S. Masuda, Tetrahedron Lett., 1978, 3447.

19) S. Tahara, M. Yoshida, J. Mizutani, C. Kitamura, S. Takahashi, Agric. Biol. Chem., 39, 1517(1975); C. Nishino, W.S. Bowers, M.E. Montgomery, L. R. Nault, ibid., 40, 2303(1976).

20) J.P. Vité, R. Hedden, K. Mori, Naturwissenshaften, 63, 43(1976).

21) J. H. Tumlison, M. G. Klein, R.E. Doolittle, T. L. Ladd, A. T. Proveaux, Science, 197, 789(1977).

22) J. H. Borden, L. Chong, J. A. McLean, K. N. Slessor, K. Mori, Science, 192, 894(1976). 
は上記と同じ条件で行なった。

$$
\begin{aligned}
& 4.2(+) \text {-ベルバニル=プロピオナート } \\
& {[\alpha]_{\mathrm{D}}=+11.2^{\circ}(c=1.0)}
\end{aligned}
$$

$\operatorname{IR}\left(\mathrm{cm}^{-1}\right): 1730(\mathrm{C}=0), 1180(\mathrm{C}-\mathrm{O})$

$\operatorname{PMR} \delta(\mathrm{ppm}): \overline{0} .86\left(3 \mathrm{H}, \mathrm{s},>\mathrm{CCH}_{3}\right), \quad 0.91 .(3 \mathrm{H}, \mathrm{d}, J=6.5$ $\left.\mathrm{Hz},>\mathrm{CHCH}_{3}\right), 1.10\left(3 \mathrm{H}, \mathrm{t}, J=7.0 \mathrm{~Hz},-\mathrm{CH}_{2} \mathrm{CH}_{3}\right), 1.24(3 \mathrm{H}$, $\left.\mathrm{s},>\mathrm{CCH}_{3}\right), \quad 5.13\left(1 \mathrm{H}, \mathrm{m},>\mathrm{CH}-\mathrm{O}_{-}\right)$

$t_{\mathrm{R}}: 11.9$

MS : m/e $210\left(\mathrm{M}^{+}, \mathrm{C}_{13} \mathrm{H}_{22} \mathrm{O}_{2}\right), \quad 195\left[\mathrm{M}^{+}-15\left(\mathrm{CH}_{3}\right)\right], \quad 181\left[\mathrm{M}^{+}\right.$ $\left.-29\left(\mathrm{CH}_{2} \mathrm{CH}_{3}\right)\right], 155,136\left[\mathrm{M}^{+}-74\left(\mathrm{C}_{2} \mathrm{H}_{5} \mathrm{CO}_{2} \mathrm{H}\right)\right], 121,107,93$ (最大ピーク)

\section{3 (一)-trans-ベルベノール}

米国 (フロリダ) SCM Gliden Organics 社から市肘されてい

るものを使用した。

$[\alpha]_{\mathrm{D}}=-122.4^{\circ}(c=1.1)\left[c f .(+)-\right.$ 体, $\left.+120.2^{\circ}\right]$

IR $\left(\mathrm{cm}^{-1}\right): 3320(\mathrm{OH}), 1650(\mathrm{C}=\mathrm{C}), 1025(\mathrm{C}-\mathrm{O})$

PMR $\delta(\mathrm{ppm}): 0.86\left(3 \mathrm{H}, \mathrm{s},>\mathrm{CCH}_{3}\right), 1,33\left(3 \mathrm{H}, \mathrm{s},>\mathrm{CCH}_{3}\right)$, 1. $71\left(3 \mathrm{H}, \mathrm{t}, J=1.5 \mathrm{~Hz},-\mathrm{CH}=\mathrm{CCH}_{3^{-}}\right), 4.24\left(1 \mathrm{H}, \mathrm{m},>\mathrm{CH}-\mathrm{O}^{-}\right)$, 5. $32\left(1 \mathrm{H}, \mathrm{m},-\mathrm{CH}=\mathrm{CCH}_{3}-\right)$

$t_{\mathrm{R}}: 9.0$

MS : m/e $134\left[\mathrm{M}^{+}-18\left(\mathrm{H}_{2} \mathrm{O}\right)\right], 119,91$ (最大ピーク)

4.4 (一)-trans-ベルベニル=アセタート [ $\boldsymbol{I}^{\prime}$ a $]$

$[\alpha]_{\mathrm{D}}=-164.5^{\circ}(c=1.0)\left[c f .(+)-\right.$ 体, $\left.+147.0^{\circ}\right]$

$\operatorname{IR}\left(\mathrm{cm}^{-1}\right): 1730(\mathrm{C}=0), 1655(\mathrm{C}=\mathrm{C}), 1240(\mathrm{C}-0)$

$\operatorname{PMR} \delta(\mathrm{ppm}): 0.92\left(3 \mathrm{H}, \mathrm{s},>\mathrm{CC}_{1} \mathrm{H}_{8}\right), 1.33\left(3 \mathrm{H}, \mathrm{s},>\mathrm{CCH}_{3}\right)$, $1.73\left(3 \mathrm{H}, \mathrm{bs},-\mathrm{CH}=\mathrm{CCH}_{3}-\right), 2.02\left(3 \mathrm{H}, \mathrm{s},-\mathrm{CO}-\mathrm{CH}_{3}\right) ; 5.37(2$ $\left.\mathrm{H}, \mathrm{bs},-\mathrm{CH}=\mathrm{CCH}_{3^{-}},>\mathrm{CH}-\mathrm{O}_{-}\right)$

$t_{\mathrm{R}}: 8.3$

MS : m/e 134[M+-60 $\left.\left(\mathrm{CH}_{3} \mathrm{CO}_{2} \mathrm{H}\right)\right], 119$ (最大ピーク), 91

4.5 (一)-trans-ベルベニル=プロビオナート[1'b]

$[\alpha]_{\mathrm{D}}=-158.2^{\circ}(c=1.0)\left[c f .(+)-\right.$ 体, $\left.+132.0^{\circ}\right]$

$\operatorname{IR}\left(\mathrm{cm}^{-1}\right): 1730(\mathrm{C}=0), 1650(\mathrm{C}=\mathrm{C}), 1180(\mathrm{C}-0)$

PMR $\delta(\mathrm{ppm}): 0.90\left(3 \mathrm{H}, \mathrm{s},>\mathrm{CCH}_{\mathrm{s}}\right), \quad 1.13(3 \mathrm{H}, \mathrm{t}, J=7.0$

$\left.\mathrm{Hz},-\mathrm{CH}_{2} \mathrm{CH}_{3}\right), \quad 1.32\left(3 \mathrm{H}, \mathrm{s},>\mathrm{CCH}_{3}\right), \quad 1.72(3 \mathrm{H}, \mathrm{s},-\mathrm{HC}=$ $\left.\mathrm{CCH}_{3^{-}}\right)$, $5.35\left(2 \mathrm{H}, \mathrm{bs},-\mathrm{HC}=\mathrm{CCH}_{3^{-}},>\mathrm{CH}-\mathrm{O}^{-}\right)$

$t_{\mathrm{R}}: 12.1$

MS : m/e 134[M $\left.\mathrm{M}^{+}-74\left(\mathrm{C}_{2} \mathrm{H}_{5} \mathrm{CO}_{2} \mathrm{H}\right)\right], 119$ (最大ビーク), 91

\section{6 (一)-trans-ペルパノール[9]の合成}

4.6.1（十)-アポヘルベノン[4]のエポキシ化：(十)-アポペ ルベノン [4] $2.7 \mathrm{~g}$ のメタノール $20 \mathrm{ml}$ 溶液を $-15^{\circ} \mathrm{C}$ に冷し， これに $30 \%$ 過酸化水素水 $7.5 \mathrm{ml}$ を加えた。この溶液に，かき まぜながら $6 \mathrm{~N}$ 水酸化ナトリウム $1.5 \mathrm{ml}$ を滴加し, 滴加終了後 さらに $-15^{\circ} \mathrm{C}$ で 1 時間かきまぜた。反応混合物を氷水に注ぎ， エーテル抽出し, 得られたエーテル層を, 水, 飽和塩化ナトリウ ム水溶液の順に洗浄したのち硫酸マグシウムで乾燥した（以後こ の洗浄および乾燥操作を「常法による処理」として表わす)。減圧 下エーテルを除去すると粗製のエポキシ化物 [5]が得られ，こ の粗生成物をシリカゲルクロマトグラフィー（へキサン：酢酸エ チル＝4：1）することにより純粋なアポベルベノンニエポキシド （5] $2.2 \mathrm{~g}$ を得た (収率 $90 \%$ )。 $\mathrm{mp} 55 \sim 59^{\circ} \mathrm{C}$ 。

$[\alpha]_{\mathrm{D}}=+156.3^{\circ}(c=1.0)$

IR $\left(\mathrm{KBr}, \mathrm{cm}^{-1}\right): 1705(\mathrm{C}=0), 1235(\mathrm{C}-0), 865$ (-Ć- ${ }^{\mathrm{O}}-$-)
PMR $\delta(\mathrm{ppm}): 1.03\left(3 \mathrm{H}, \mathrm{s},>\mathrm{CCH}_{3}\right), 1.40\left(3 \mathrm{H}, \mathrm{s},>\mathrm{CCH}_{3}\right)$, $3.31\left(1 \mathrm{H}, \mathrm{q}, J=1.0,4.0 \mathrm{~Hz},\left(-\mathrm{HC}_{-}{ }_{-\mathrm{C}} \mathrm{H}-\right), 3.64(1 \mathrm{H}, \mathrm{d}, J=\right.$ $\left.4.0 \mathrm{~Hz},-\mathrm{HC}-\mathrm{C}^{\mathrm{O}} \mathrm{C} H-\right)$

$t_{\mathrm{R}}: 10.2$

MS : m/e $152\left(\mathrm{M}^{+}, \mathrm{C}_{9} \mathrm{H}_{12} \mathrm{O}_{2}\right), \quad 137\left[\mathrm{M}^{+}-15\left(\mathrm{CH}_{3}\right)\right], \quad 123[137$ $\left.-15\left(\mathrm{CH}_{3}\right)\right], 109,95$ (最大ピーク)

4.6 .2 (一)-trans-アポベルベノール [6]:[5]の $5.7 \mathrm{~g}$ メタノール $60 \mathrm{~m} l$ に溶かし，かきまぜながら $0^{\circ} \mathrm{C}$ で抱水ヒドラ ジン $60 \mathrm{ml}$ を滴加した。滴加後酢酸 $4.5 \mathrm{ml}$ を加光, 減圧下溶 媒を除去し，水 $50 \mathrm{~m} l$ を加えてェーテルで抽出した。エーテル 層を常法で処理したのち，エーテルを留去して生じた青黄色の油 状物をシリカゲルクロマトグラフィー（ヘキサン：酢酸エチル＝ $5: 1$ ) することにより，〔6]1.1g を得た（収率 21\%)。

$[\alpha]_{\mathrm{D}}=-146.2^{\circ}(c=1.0)\left[c f .(+)-\right.$ 体, $\left.+147.0^{\circ}\right]$

IR $\left(\mathrm{cm}^{-1}\right): 3280(\mathrm{OH}), 1650(\mathrm{C}=\mathrm{C}), 1025(\mathrm{C}-0)$

PMR $\delta(\mathrm{ppm}): 1.11\left(3 \mathrm{H}, \mathrm{s},>\mathrm{CCH}_{3}\right), 1.35\left(3 \mathrm{H}, \mathrm{s},>\mathrm{CCH}_{3}\right)$ 4.50 ( $1 \mathrm{H}$, bs, > CH-O-), 5. 68 ( $1 \mathrm{H}, \mathrm{bd}, J=8.5 \mathrm{~Hz},-\mathrm{HC}=\mathrm{CH}-$ ), $6.30(1 \mathrm{H}, \mathrm{q}, J=6.5,8.5 \mathrm{~Hz},-\mathrm{HC}=\mathrm{CH}-)$

$t_{\mathrm{R}}: 5.5$

MS : $m / e 138\left(\mathrm{M}^{+}, \mathrm{C}_{9} \mathrm{H}_{14} \mathrm{O}\right), 123\left[\mathrm{M}^{+}-15\left(\mathrm{CH}_{3}\right)\right], 120\left[\mathrm{M}^{+}-\right.$ $\left.18\left(\mathrm{H}_{2} \mathrm{O}\right)\right], 109,107,95$ (最大ピーク), 91

4.6 .3 (一)-アポベルベノン [4']:[6]の $620 \mathrm{mg}$ をへキサ ソ $30 \mathrm{ml}$ に溶かし，さらにこの溶液に，よく粉砕した活性酸化 マンガン $(\mathbb{N}) 6 \mathrm{~g}$ を加えて室温で一夜かきまぜた。この反応液を 汇過して得られた沪夜の濃縮物をシリカゲルクロマトグラフィ

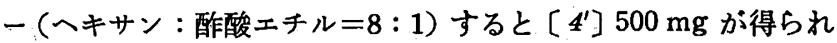
た (収率 $82 \%$ )。

$[\alpha]_{\mathrm{D}}=-296.3^{\circ}(c=1.0),\left[c f .(+)-\right.$ 体, $\left.+283.2^{\circ}\right]$

$\operatorname{IR}\left(\mathrm{cm}^{-1}\right): 1690(\mathrm{C}=0), 1620(\mathrm{C}=\mathrm{C}), 1250,1045(\mathrm{C}-0)$

PMR $\delta(\mathrm{ppm}): 1.03\left(3 \mathrm{H}, \mathrm{s},>\mathrm{CCH}_{3}\right), 1.53\left(3 \mathrm{H}, \mathrm{s},>\mathrm{CCH}_{3}\right)$, $5.96(1 \mathrm{H}, \mathrm{dt}, J=1.0,9.0 \mathrm{~Hz},-\mathrm{HC}=\mathrm{CH}-), 7.53(1 \mathrm{H}, \mathrm{dq}, J=$ 1. $0,5.0,9.0 \mathrm{~Hz},-\mathrm{HC}=\mathrm{CH}-$ )

$t_{\mathrm{R}}: 7.6$

MS : m/e $136\left(\mathrm{M}^{+}, \mathrm{C}_{9} \mathrm{H}_{12} \mathrm{O}\right), 121\left[\mathrm{M}^{+}-15\left(\mathrm{CH}_{3}\right)\right], \quad 108\left[\mathrm{M}^{+}-\right.$ 28(CO)], 93 (最大ピーク), 91

4.6 .4 (一)-trans-ベルバノン[7]：ヨウ化銅 ( I ) $950 \mathrm{mg}$ を エーテル $10 \mathrm{ml}$ に懸濁し，これにメチルリチウム $1.6 \mathrm{~mol}$ のへキ サン溶液 $5 \mathrm{~m} l$ と, 少量のエーテルとの混合液を $-76^{\circ} \mathrm{C}$ アルゴン 気流中で徐々に滴加した。滴加後，反応物を氷水浴中で 5 分間か きまぜ,これに[ $\left.4^{\prime}\right] 500 \mathrm{mg}$ の $1 \mathrm{ml}$ エーテル溶液を滴加した。 つづいて飽和塩化アンモニウム溶液を過剩に加えたのち，沪過し た。汇別した沈殿をエーテルで数回洗い，汇液もエーテル抽出し すべてのエーテル層を合わせたのち，常法で処理し減圧でェーテ ルを除くと, 粗製の〔7]が得られた。粗生成物のシリカゲルク ロマトグラフィー（ヘキサン：酢酸エチル＝10：1）により純粋 な〔7] $451 \mathrm{mg}$ を得た（収率 $81 \%$ )。

$[\alpha]_{\mathrm{D}}=-28.6^{\circ}(c=1.0)\left[c f .(+)-\right.$-体, $\left.+28.3^{\circ}\right]$

IR $\left(\mathrm{cm}^{-1}\right): 1710(\mathrm{C}=0), 1460\left(\mathbf{C H}_{2} \mathrm{CO}\right)$

PMR $\delta(\mathrm{ppm}): 0.85\left(3 \mathrm{H}, \mathrm{s},>\mathrm{CCH}_{3}\right), \quad 1.04(3 \mathrm{H}, \mathrm{d}, J=7.0$ $\left.\mathrm{Hz},>\mathrm{CHCH}_{3}\right), \quad 1.33\left(3 \mathrm{H}, \mathrm{s},>\mathrm{CCH}_{3}\right)$

$t_{\mathrm{R}}: 9.3$

MS : m/e $152\left(\mathrm{M}^{+}, \mathrm{C}_{10} \mathrm{H}_{18} \mathrm{O}\right), 137\left[\mathrm{M}^{+}-15\left(\mathrm{CH}_{3}\right)\right], 109,95$, 
83 (最大ビーク)

4.6.5（十)-ネオヘルパノール[8]と（一)-ベルパノール [9]: 実験直前に細かく切ったアルミニウムハク $100 \mathrm{mg}$ と塩化 水銀(II) $3 \mathrm{mg}$ を-プロパノール $2 \mathrm{ml}$ の中に入れ, 1.5 時間

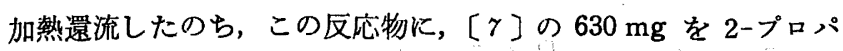
ノール $0.5 \mathrm{~m} l$ に溶かした溶液を加えた。生じた青黑色の溶液か らアセトンを留去しながら，5時間加熱還流したのち，反応液を $1 \mathrm{~N}$ 塩酸に注ぎ, エーテルで抽出した。エーテル層を常法により 処理し, 減圧下エーテルを除去して得られた残留物をシリカゲル クロマトダラフィー（ヘキサン：酢酸エチル=7:1）することに より〔8〕 $279 \mathrm{mg}$ (収率 45\%) と〔9] $232 \mathrm{mg}$ (同 37\%) を得た。

[8]: $\mathrm{mp} 77 \sim 78^{\circ} \mathrm{C}$

$[\alpha]_{\mathrm{D}}=+15.3^{\circ}(c=1.0)\left[c f .(-)-\right.$ 体, $\left.-16.5^{\circ}\right]$

$\mathrm{IR}\left(\mathrm{KBr}, \mathrm{cm}^{-1}\right): 3300(\mathrm{OH}), 1110(\mathrm{C}-\mathrm{O})$

PMR $\delta(\mathrm{ppm}): 0.80\left(3 \mathrm{H}, \mathrm{d}, J=6.5 \mathrm{~Hz},>\mathrm{CHCH}_{3}\right), \quad 1.08(3$ $\left.\dot{\mathrm{H}}, \mathrm{s},>\mathrm{CCH}_{3}\right), \quad 1.23\left(3 \mathrm{H}, \mathrm{s},>\mathrm{CCH}_{3}\right), \quad 4.23(1 \mathrm{H}, \mathrm{m},>\mathrm{CH}-$ 0-)

$t_{\mathrm{R}}: 9.0$

MS : m/e $139\left[\mathrm{M}^{+}-15\left(\mathrm{CH}_{3}\right)\right], 121\left[139-18\left(\mathrm{H}_{2} \mathrm{O}\right)\right], 107,97$, 95,83 (最大ピーク)

[9]: $\operatorname{mp~} 54 \sim 55^{\circ} \mathrm{C}$

$[\alpha]_{\mathrm{D}}=-7.8^{\circ}(c=1.0)\left[c f .(+)-\right.$ 体, $\left.+8.4^{\circ}\right]$

$\mathrm{IR}\left(\mathrm{KBr}, \mathrm{cm}^{-1}\right): 3280(\mathrm{OH}), 1120(\mathrm{C}-\mathrm{O})$

PMR $\delta(\mathrm{ppm}): 0.79\left(3 \mathrm{H}, \mathrm{s},>\mathrm{CCH}_{3}\right), \quad 0.90(3 \mathrm{H}, \mathrm{d}, J=6.5$ $\left.\mathrm{Hz},>\mathrm{CHCH}_{3}\right), \quad 1.23\left(3 \mathrm{H}, \mathrm{s},>\mathrm{CCH}_{3}\right), \quad 4.08(1 \mathrm{H}, \mathrm{m},>\mathrm{CH}-$ $0-)$.

$t_{\mathrm{R}}: 10.44$

MS : m/e 139[M+-15( $\left.\left(\mathrm{CH}_{3}\right)\right], 121\left[139-18\left(\mathrm{H}_{2} \mathrm{O}\right)\right], 107,97$, 95,83 (最大ピーク)

4.7 (一)-ペルバニルーアセタート [2' a $]$

$[\alpha]_{\mathrm{D}}=-12.5^{\circ}(c=1.0)\left[c f .(+)-\right.$ 体, $\left.+10.0^{\circ}\right]$

$\operatorname{IR}\left(\mathrm{cm}^{-1}\right): 1730(\mathrm{C}=0), 1250(\mathrm{C}-\mathrm{O})$

PMR $\delta(\mathrm{ppm}): 0.85\left(3 \mathrm{H}, \mathrm{s},>\mathrm{CCH}_{3}\right), \quad 0.91(3 \mathrm{H}, \mathrm{d}, J=7.0$ $\left.\mathrm{Hz},>\mathrm{CHCH}_{3}\right), 1.23\left(3 \mathrm{H}, \mathrm{s},>\mathrm{CCH}_{3}\right), 1.98\left(3 \mathrm{H}, \mathrm{s},-\mathrm{CO}-\mathrm{CH}_{3}\right)$, $5.12\left(1 \mathrm{H}, \mathrm{m},>\mathrm{CH}-\mathrm{O}_{-}\right)$

$t_{\mathrm{R}}: 9.3$

MS : m/e $196\left(\mathrm{M}^{+}, \mathrm{C}_{12} \mathrm{H}_{20} \mathrm{O}_{2}\right), \quad 154\left[\mathrm{M}^{+}-42\left(\mathrm{CH}_{2} \mathrm{CO}\right)\right], 136$ $\left[\mathrm{M}^{+}-60\left(\mathrm{CH}_{3} \mathrm{CO}_{2} \mathrm{H}\right)\right], 121,107,93$ (最大ピーク)

4.8 (一)-ベルバニル=プロビオナート $\left[2^{\prime} b\right]$

$[\alpha]_{\mathrm{D}}=-11.6(c=1.0)\left[c f .(+)-\right.$ 体, $\left.+11.2^{\circ}\right]$
$\operatorname{IR}\left(\mathrm{cm}^{-1}\right): 1730(\mathrm{C}=0), 1180(\mathrm{C}-0)$

$\operatorname{PMR} \delta(\mathrm{ppm}): 0.88\left(3 \mathrm{H}, \mathrm{s},>\mathrm{CCH}_{3}\right), \quad 0.93(3 \mathrm{H}, \mathrm{d}, J=5.5$ $\left.\mathrm{Hz},>\mathrm{CHCH}_{3}\right), 1.10\left(3 \mathrm{H}, \mathrm{t}, J=8.0 \mathrm{~Hz},-\mathrm{CH}_{2} \mathrm{CH}_{3}\right), 1.25(3 \mathrm{H}$, $\left.\mathrm{s},>\mathrm{CCH}_{3}\right), \quad 5.15\left(1 \mathrm{H}, \mathrm{m},>\mathrm{CH}-\mathrm{O}_{-}\right)$

$t_{\mathrm{R}}: 13.6$

MS : $m / e ~ 210\left(\mathrm{M}^{+}, \mathrm{C}_{18} \mathrm{H}_{22} \mathrm{O}_{2}\right), 196,181\left[\mathrm{M}^{+}-29\left(\mathrm{C}_{2} \mathrm{H}_{5}\right)\right], 154$ $\left[\mathrm{M}^{+}-56\left(\mathrm{C}_{2} \mathrm{H}_{4} \mathrm{CO}\right)\right], \quad 136\left[\mathrm{M}^{+}-74\left(\mathrm{C}_{2} \mathrm{H}_{5} \mathrm{CO}_{2} \mathrm{H}\right)\right], \quad 121,107,93$ (最大ピーク)

4.9 (十)-ネオベルバニル=アセタート[ $\left[3^{\prime}\right.$ a $]$

$[\alpha]_{\mathrm{D}}=+9.5^{\circ}(c=1.0)\left[c f .(-)-\right.$ 体, $\left.-9.0^{\circ}\right]$

$\operatorname{IR}\left(\mathrm{cm}^{-1}\right): 1730(\mathrm{C}=0), 1250(\mathrm{C}-0)$

PMR $\delta(\mathrm{ppm}): 0.92\left(3 \mathrm{H}, \mathrm{d}, J=6.0 \mathrm{~Hz},>\mathrm{CHCH}_{3}\right), 1.00$ (3 $\left.\mathrm{H}, \mathrm{s},>\mathrm{CCH}_{3}\right), 1.22\left(3 \mathrm{H}, \mathrm{s},>\mathrm{CCH}_{3}\right) ; 1.98\left(3 \mathrm{H}, \mathrm{s},-\mathrm{CO}-\mathrm{CH}_{3}\right)$, 5. $20(1 \mathrm{H}, \mathrm{m},>\mathrm{CH}-\mathrm{O}-)$

$t_{\mathrm{R}}: 9.8$

MS : m/e $196\left(\mathrm{M}^{+}, \mathrm{C}_{12} \mathrm{H}_{20} \mathrm{O}_{2}\right), \quad 154\left[\mathrm{M}^{+}-42\left(\mathrm{CH}_{2} \mathrm{CO}\right)\right], \quad 136$ $\left[\mathrm{M}^{+}-60\left(\mathrm{CH}_{3} \mathrm{CO}_{2} \mathrm{H}\right)\right], 121,107,93$ (最大ピーク)

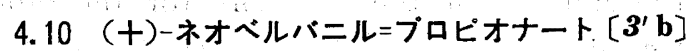

$[\alpha]_{\mathrm{D}}=+8.0(c=1.0)$

$\mathrm{IR}\left(\mathrm{cm}^{-1}\right): 1730(\mathrm{C}=0), 1180(\mathrm{C}-0)$

PMR $\delta(\mathrm{ppm}): 0.89\left(3 \mathrm{H}, \mathrm{d}, J=7.0 \mathrm{~Hz},>\mathrm{CHCH}_{3}\right), 1.02(3$ $\left.\mathrm{H}, \mathrm{s},>\mathrm{CCH}_{3}\right), 1.10\left(3 \mathrm{H}, \mathrm{t}, J=6.0 \mathrm{~Hz},-\mathrm{CH}_{2} \mathrm{CH}_{3}\right), 1.22(3 \mathrm{H}$, $\left.\mathrm{s},>\mathrm{CCH}_{3}\right), \quad 5.22\left(1 \mathrm{H}, \mathrm{m},>\mathrm{CH}-\mathrm{O}_{-}\right)$

$t_{\mathrm{R}}: 14.8$

MS : m/e $210\left(\mathrm{M}^{+}, \mathrm{C}_{13} \mathrm{H}_{22} \mathrm{O}_{2}\right), 196,181\left[\mathrm{M}^{+}-29\left(\mathrm{C}_{2} \mathrm{H}_{5}\right)\right], 154$ $\left[\mathrm{M}^{+}-56\left(\mathrm{C}_{2} \mathrm{H}_{4} \mathrm{CO}\right)\right], \quad 136\left[\mathrm{M}^{+}-74\left(\mathrm{C}_{2} \mathrm{H}_{5} \mathrm{CO}_{2} \mathrm{H}\right)\right], \quad 121,107,93$ (最大ピーク)

\subsection{1 生理活性試験}

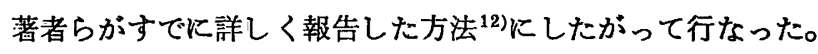
試験法の概略はつぎのとおりである。

ワモンゴキブリの雌成虫から，少なくとも 1 箅月以上隔離して 育てられた雄成虫を 25 頭ずつ飼育箱に入れて, 雄専用の飼育室 $\left(26^{\circ} \mathrm{C}, 40 \% \mathrm{RH}\right.$, 午前 9 時 午後 4 時：明期，午後 4 時〜午前 9 時：暗期，生理活性試験室を兼ねる）で飼育したるのを試験に用 いた。試験は月曜日または木䍜日の午後 9 時〜 9 時 30 分に開始 しほほのな光のもとで行なった。一定量の試験化合物を含んた 沪紙を飼育箱に入れたのち，3分間に特徵ある性行動を示した頭 数を数えた。一度試験に使用した飼育箱は, 少なくとも 3 日間は 使用しなかった。 


\title{
Special Articles on
}

Biologically Active Substances

\section{Pheromonal Activity of Optical Isomers of Sex Pheromone Mimics in the American Cockroach}

\author{
Hisao Takayanagi and Chikao Nishino* \\ Mitsubishi-Kasei Institute of Life Sciences: \\ Minamiooya, Machida-shi. 194 Japan
}

In addition to the known sex pheromone mimics of the American cockroach; $(+)$-transverbenyl acetate $[1 \mathrm{a}],(+)$-trans-verbenyl propionate $[1 \mathrm{~b}]$ and $(+)$-verbanyl acetate $[2 \mathrm{a}]$, $(+)$-verbanyl propionate $[2 \mathrm{~b}]$ was prepared. Eighteen of 25 males of the cockroach were sexually elicited by $0.02 \mathrm{mg}$ of $[2 \mathrm{~b}]$, which was most active among the mimics. Antipodes $[(-)$-isomers $]$ of the mimics, $\left[1^{\prime} \mathrm{a}\right],\left[1^{\prime} \mathrm{b}\right],\left[2^{\prime} \mathrm{a}\right]$ and $\left[2^{\prime} \mathrm{b}\right]$, were synthesized to elucidate the chirality of the receptors for the mimics. A commercially obtained (-)-trans-verbenol was used for $\left[1^{\prime} \mathrm{a}\right]$ and $\left[1^{\prime} \mathrm{b}\right]$, 'whereas $(-)$-verbanol $[9]$ synthesized in the present work for $\left[2^{\prime} \mathrm{a}\right]$ and $\left[2^{\prime} \mathrm{b}\right]$.

$(+)$-Apoverbenone [4] was converted into its antipode [4'] via [5] and [6]. [4 $\left[4^{\prime}\right]$ was methylated to yield $(-)$-trans-verbanone $[7]$. Meerwein-Ponndorf reduction of $[7]$ : afforded [9] with (+)-neoverbanol [8] (Scheme 1). Since no pheromonal activity was observed in any (-)-isomer at the dosage of $0.3 \mathrm{mg}$, the receptor for the mimics was elucidated to possess a chirality. This fact supports the chiral property of the sex pheromone receptor of this insect which responds to an optical isomer of the sex pheromone, periplanone-B, but not to its antipode. 